Bryant University

Bryant Digital Repository

8-2016

\title{
Size Variables in Audit Fee Models: An Examination of the Effects of Alternative Mathematical Transformations
}

Charles Cullinan

Bryant University, cullinan@bryant.edu

Hui Du

University of Houston - Clear Lake

Xiaochuan Zheng

Bryant University, xzheng@bryant.edu

Follow this and additional works at: https://digitalcommons.bryant.edu/acc_jou

Part of the Accounting Commons, and the Mathematics Commons

\section{Recommended Citation}

Cullinan, Charles; Du, Hui; and Zheng, Xiaochuan, "Size Variables in Audit Fee Models: An Examination of the Effects of Alternative Mathematical Transformations" (2016). Accounting Journal Articles. Paper 152.

https://digitalcommons.bryant.edu/acc_jou/152

This Article is brought to you for free and open access by the Accounting Faculty Publications and Research at Bryant Digital Repository. It has been accepted for inclusion in Accounting Journal Articles by an authorized administrator of Bryant Digital Repository. For more information, please contact dcommons@bryant.edu. 


\title{
Size Variables in Audit Fee Models: An Examination of the Effects of Alternative Mathematical Transformations
}

\author{
Charles P. Cullinan \\ Bryant University \\ Hui Du \\ University of Houston-Clear Lake \\ Xiaochuan Zheng \\ Bryant University
}

\begin{abstract}
SUMMARY: We consider the mathematical transformations used for assets of different valuation complexity in audit fee models. These mathematical transformations (such as logs and square roots) relate to the non-linear relationship between client size and audit fees. We use closed-end mutual fund audits to examine this question because virtually all fund assets are reported at fair value. We find that more complexly valued assets are less likely to follow the traditional log transformation because the presence of these assets has a stronger relationship with audit fees that is not fully captured by the coefficient on the logged variable alone. The significance of nonsize variables was also found to differ in audit fee models of both closed-end funds and a broad-based sample of public companies when the mathematical transformation of size variables was permitted to vary. These results suggest that the non-linear relationship between client size and audit fees may not always be sufficiently captured by a log transformation and that future audit fee studies should consider different size transformations to test size measures and to more robustly assess the significance of other variables in audit fee models that may be of interest.
\end{abstract}

Keywords: audit fee; fair valued assets; closed-end mutual funds; non-linear.

\section{INTRODUCTION}

$\mathrm{C}$

ompany size, typically measured as total assets, is an important factor in audit fee models (Hay, Knechel, and Wong 2006). The size measure is usually transformed by taking the natural logarithm of total assets (e.g., Craswell, Francis, and Taylor 1995; Ferguson, Francis, and Stokes 2003; Francis, Reichelt, and Wang 2005; Fan and Wong 2005). This $\log$ transformation of assets (and audit fees) was first used by Simunic's (1980) seminal study of audit fees. The log of assets and the log of audit fees have since been used in audit fee studies to control for the non-linear relationship between asset size and audit fees.

The relationship between assets and audit fees may be non-linear for two main reasons. First, as the population size increases (e.g., the number of individual assets held), the sample size necessary to audit this larger population size is only minimally affected (Simunic 1980; Louwers, Ramsay, Sinason, Strawser, and Thibodeau 2013). Simunic (1980, 172) specifically notes the following to explain a non-linear relationship in audit fee models:

To the extent that increases in the measured total assets of auditees reflect increases in the number of individual elements which comprise the accounting populations of which total assets are composed, then the sample size will increase at a decreasing rate. Thus, I hypothesized that the positive relationship between assets and [audit fees] is nonlinear. (emphasis added)

The authors gratefully acknowledge helpful comments received from participants at the 2013 AAA Annual Meeting and the 2014 AAA Auditing Midyear Meeting, especially Chris Hogan, and from workshop participants at Bryant University.

Editor's note: Accepted by Marleen Willekens. 
Second, an auditor's evaluation of internal control processes for transaction types (e.g., the valuation process for financial assets) would probably involve a comparable level of effort for clients of different size. For example, the evaluation of the internal control process for a client with $\$ 10$ million of assets is likely to involve effort similar to the evaluation of internal control for a client with $\$ 15$ million of assets. Wallace (1980) notes that auditor litigation costs such as insurance premiums are also likely to be a non-linear function of client size.

Simunic $(1980,179)$ expected a non-linear relationship between assets and audit fees, but he noted the "absence of a theory from which [to determine] the form of the function" and made "certain ex-post modifications ... after a preliminary analysis of the data" (Simunic 1980, 180). Based on his analyses, he settled on the use of the log transformation of assets (and the log of audit fees) as the best-fitting model of the empirical relationship between client size (measured by total assets) and audit fees.

At the time of the original Simunic (1980) study, fair value accounting was less commonly used and the financial reporting standards did not clearly differentiate different types of valuation inputs that might be used to measure fair value. ASC 820 (FASB 2011) requires the disclosure of whether fair values were determined based on directly observable inputs (Level 1), indirectly observable inputs (Level 2), or unobservable inputs (Level 3). Recent research suggests that different types of fair valued assets may have different relationships with audit fees (e.g., Ettredge, Xu, and Yi 2014; Goncharov, Riedl, and Sellhorn 2014). Assets valued using more complex and subjective valuation processes (e.g., Levels 2 and 3 ) are generally associated with higher audit fees than assets valued using more objective valuation processes. Recent research has also examined whether the log transformation of audit fees (the dependent variable) may still be most appropriate (e.g., Picconi and Reynolds 2013).

We combine these two insights regarding fair valued assets and mathematical transformations to examine whether the log transformation of different types of fair valued assets provides the best fit in an audit fee model, or whether other mathematical transformations (many of which were also assessed in Simunic 1980) may better reflect the non-linear nature of the relationship between different types of fair valued assets (as independent variables) and audit fees (as the dependent variable). We also assess whether permitting the transformation of asset variables to vary may influence the interpretation of other variables in audit fee models.

We examine these issues in audit fee models among closed-end mutual funds and among a broad-based sample of publicly traded companies. The closed-end mutual fund setting is particularly appropriate for examining the relationship between fair valued assets and audit fees because virtually all of a mutual fund's assets are reported at fair value. ${ }^{1}$ In addition, closed-end mutual funds often invest in securities that are not actively traded (Cherkes, Sagi, and Stanton 2009) (i.e., assets valued using Level 2 [indirectly observable] and Level 3 [unobservable inputs]), where management has more valuation discretion and therefore more audit judgment is required to assess fair presentation.

For the closed-end fund audit fee model, the log transformation provides the best fit for Level 1 valued assets, while a square root transformation provides the best fit for assets valued using Level 2 inputs, and cube root best fits Level 3 valued assets. The results are consistent with the idea that auditing the fair value of assets valued using Level 2 and Level 3 inputs may be more costly for auditors because they have to assess management's evaluation of indirectly observable inputs (such as benchmark securities) and/or management's own estimates of future cash flows and discount rates. For the broad-based sample, the audit fee model also indicates that the log transformation alone may not fully capture the non-linear relationship between assets of different levels of complexity and audit fees.

For both the closed-end fund and broad-based samples, we also find that the significance of the other (non-size) variables in the audit fee models can differ when the transformations of the size variables are allowed to vary. These finding suggest that a more rigorous test of non-size variables can be performed when the size variables are permitted to follow a better-fitting mathematical transformation.

We contribute to the literature by assessing whether the log of assets/log of audit fees relationship best reflects the nonlinear relationship between assets of differing complexity and audit fees. This is particularly relevant when fair value accounting plays an important role in asset valuation and auditing (e.g., Ryan 2008; Song, Thomas, and Yi 2010; Ettredge et al. 2014). We also complement Fields, Fraser, and Wilkins (2004), who incorporated variables to measure unique risks and balance sheet structure in the pricing of audit services for financial institutions by considering alternative mathematical transformations of financial assets to reflect the complexity of auditing assets in the financial industry.

The remainder of the paper is organized as follows. We present the background and our research questions in the next section. The research method is then discussed, followed by the presentation of the results. In the final section, we provide conclusions and discuss the implications of our findings.

\footnotetext{
${ }^{1}$ In our sample, an average of 98.2 percent of the fund's assets are reported at fair value.
} 


\section{BACKGROUND THEORY AND RESEARCH QUESTIONS}

\section{Mathematical Transformations to Reflect Non-Linearity in Audit Fee Models}

Regression analysis assumes that the relationship between the independent and dependent variables is linear. If a relationship between the independent and dependent variable is non-linear, then the data must be transformed to reflect a more linear relationship. Simunic (1980) noted that there was a theoretical reason to expect a non-linear relationship between client size (measured as total assets) and audit fees, but he also noted that there was no theory indicating which mathematical form that relationship might exhibit. After trying other transformations (such as square root transformations), Simunic (1980) found that the $\log$ of assets and the $\log$ of audit fee provided the best fit for his data. Log transformations are often used to create a linear function for economic phenomena that are non-linear (Sydsaeter and Hammond 1995) and log transformations can help to normalize data when the distribution is skewed (Benoit 2011).

In subsequent audit fee studies, Francis (1984) and Simon (1985) follow the log transformations used in Simunic (1980) and find good linear fits. Strong linear model fits using log transformations have also been found in Australia (Francis 1984), New Zealand (Firth 1985), and Canada (Chung and Lindsay 1988). ${ }^{2}$ Later studies routinely use a log transformation for assets when examining audit fees (e.g., Craswell et al. 1995; Ferguson et al. 2003; Francis et al. 2005). More recently, Picconi and Reynolds (2013) question the assumption of constant elasticity implied by the log-log transformation and challenge researchers to study the form of the relationship between audit fees and client size in audit fee models.

Many audit fees studies (e.g., Simunic 1980; Craswell et al. 1995; Ferguson et al. 2003; Francis et al. 2005; Fan and Wong 2005) exclude financial services firms from their analyses because these firms have different balance sheet structures than many other industries and are subject to heavier regulations and more rigorous internal control. Studies investigating the pricing of audit services among various types of financial service companies (e.g., Cullinan 2002; Fields et al. 2004; Ettredge et al. 2014) also use log transformations of size variables in their audit fee models.

\section{Fair Value Reporting and Auditing}

Accounting Standards Codification (ASC) $820^{3}$ established a three-level hierarchy of inputs to measure fair value. Level 1 inputs are directly observable, such as quoted prices in active markets for identical assets or liabilities. Level 2 inputs are indirectly observable, such as quoted prices for similar assets or liabilities. Level 3 inputs are unobservable and "reflect the reporting entity's own assumptions about the assumptions that market participants would use in pricing the asset or liability" (FASB 2011). The corresponding International Financial Reporting Standards 13 (IASB 2011) is materially consistent with the U.S. reporting standards.

These indirect (i.e., Level 2) and unobservable (i.e., Level 3) inputs are inherently subject to managerial errors or bias (Benston 2008; Landsman 2007; Penman 2007; Ryan 2008). The accounting literature has documented the difficulties of auditing subjective fair value measurements when substantial judgment and decision making are involved (e.g., Barlev and Haddad 2004; Martin, Rich, and Wilks 2006). The difficulty of auditing subjective fair values has been found to be associated with higher audit fees (e.g., Ettredge et al. 2014; Goncharov et al. 2014).

\section{The Mutual Fund Reporting and Audit Environment}

Closed-end mutual funds have long been regulated by the Investment Company Act of 1940, which requires that their investments be reported at fair value. In accordance with the three-level fair value hierarchy of ASC 820, closed-end mutual funds report the total dollar amount of their assets that are valued using Level 1, Level 2, and Level 3 inputs. Because closed-end mutual funds report virtually all assets and liabilities at fair value (Carroll, Linsmeier, and Petroni 2003), these funds provide a unique setting in which to examine the relationship between assets valued using different valuation inputs and audit fees. Mutual fund audits also have more extensive audit testing than most other types of audits. Auditors are

\footnotetext{
${ }^{2}$ Chung and Lindsay (1988) alternatively divide audit fees by the square root of assets to control for non-linearity.

${ }^{3}$ Originally issued as SFAS No. 157 (FASB 2006).
} 
expected to test the existence ${ }^{4}$ and valuation of all of the assets held by the fund (AICPA 2012, $\left.92.181,2^{-198}\right)^{5,6}$ due to the low level of materiality in mutual fund financial statements. ${ }^{7}$

Regulators have found cases in which mutual fund assets were mis-valued (e.g., SEC 2011, 2012a, 2012b, 2013). The SEC (2013) provides a listing of the 53 enforcement actions they have issued against funds for 34 instances of asset mis-valuations. ${ }^{8}$ We read these enforcement actions to determine the types of assets mis-valued. We found that among the types of assets misvalued, 33 cases (97.1 percent) related to assets from inactive markets (i.e., assets using Level 2 and Level 3 valuation inputs), ${ }^{9}$ while only one enforcement action (2.9 percent) related to assets from active markets (i.e., assets using Level 1 valuation input). While the base level of assets in inactive markets versus active markets cannot be consistently measured across the time period (from 1943 to 2013) covered by these mis-valuations, the SEC enforcement actions suggest that fair value assets using Level 2 and Level 3 valuation inputs have higher misstatement risk. ${ }^{10}$ De Jonghe and Vrolix $(2005,416)$ note that "the quality of the NAV (Net Asset Value) depends directly on the quality of the valuation of the underlying assets."

\section{Research Questions}

Level 1 valuation inputs are directly observable. Auditing the valuation assertion of Level 1 assets held by closed-end funds can be relatively straightforward, as these Level 1 assets are all actively traded securities. To audit the valuation of Level 1 securities, the auditor can simply verify the price per share of the security and multiply the verified price by the number of shares held. The auditing process for assets valued using Level 1 inputs can be standardized and performed largely electronically or by less experienced audit staff. ${ }^{11}$

Level 2 valuation inputs are indirectly observable. Assets valued using Level 2 inputs are often based on quoted prices for similar assets, such as bonds with similar maturities and bond ratings. For Level 2 assets, auditors consider whether the client has selected appropriate indirectly observable inputs. The auditor could, for example, assess whether a client has chosen an appropriate benchmark security to measure the inputs, and then recompute the valuation based on these inputs. Unlike the audit process for Level 1 assets, the audit process for Level 2 assets involves more audit judgment and cannot easily be routinized. Moreover, SAS No. 99 (AICPA 2002) indicates that assets valued using more subjective estimates may increase the likelihood of misstatement, which requires the auditor to respond with more (and higher quality) substantive testing procedures. Because Level 2 assets are more complex to audit, we expect that these Level 2 assets will have a larger effect on audit fees than Level 1 assets.

Level 3 inputs are unobservable inputs that reflect the reporting entity's own assumptions (ASC 820, FASB 2011) and are most likely to be subject to potential errors and bias by management. To verify the Level 3 fair value assets, auditors must perform extensive work to examine the valuation techniques and test various appraisal models. Consistent with other studies (e.g., Ettredge et al. 2014), we expect Level 3 assets to be the most complex fair valued assets to audit and thus that Level 3 assets will have the steepest relationship with audit fees compared to Level 2 and Level 1 assets.

The stronger effects of complexly valued assets on audit fees could be captured by larger coefficients on the variables measuring the different types of assets using the traditional log transformation. The differences in audit complexity of each type of asset could also result in a mathematical transformation other than the log transformation being the most appropriate measure, as some mathematical transformations are steeper than others (assuming the same coefficient). Due to the complexity

\footnotetext{
${ }^{4}$ The effort necessary (and thus the audit fees associated with) testing the existence assertion are not expected to vary based on valuation inputs. Testing existence requires the auditor to confirm the securities held by the custodian and/or broker (AICPA 2012, 9 2.181).

5 The PCAOB standards are applicable to the audits of closed-end funds. The AICPA (2012) citation is to the AICPA Industry Audit Guide for Investment Companies, which incorporates the PCAOB standards for publicly traded investment companies (including closed-end funds).

6 Note that for the existence assertion, the auditor "should" (AICPA 2012, 2.181) test all securities. While for the valuation assertion the auditor "could" (AICPA 2012, - 2.198) test all securities. In the next sentence, the AICPA indicates that the extent of valuation testing is a matter of auditor judgment if the fund is not a registered fund. This phrasing indicates that for registered funds, the extent of valuation testing is not a matter of judgment, and that all valuations should be examined. Closed-end mutual funds are registered funds, in which auditors are therefore expected to test all of the asset valuations.

${ }^{7}$ In accordance with SEC Regulations $(\$ 270.2 \mathrm{a}-4(6)(\mathrm{b}))$, when preparing the financial statements of mutual funds, financial statement preparers must account for any item that can cause a change in net asset value of one cent per share. Goldstein $(2009,4)$ notes that "[ $t$ ]his standard has given rise to the so-called 'penny per share rule,' which is often applied as a materiality standard for the correction [by fund management companies] of accounting errors of any kind (not just income or expense matters)."

${ }^{8}$ Among the 53 enforcement actions, 17 were related to duplicate instances of asset mis-valuations (often the SEC sanctions multiple parties for the same mis-valuation) and two were related to money market mutual funds, which have somewhat different valuation requirements. Thus, 34 out of the 53 enforcement actions are unique instances of mis-valuation by non-money-market mutual funds.

${ }^{9}$ One of these cases involved a related-party receivable.

${ }^{10}$ Because virtually of all of the misstatements occurred before the issuance of the ASC 820 (i.e., SFAS No. 157), we cannot clearly determine whether the misstatements related to Level 2 or Level 3 valued assets. However, by reading the enforcement action, we were able to ascertain whether the assets mis-valued were actively traded (i.e., Level 1 ).

11 At the 2012 PwC Accounting Symposium for Professors, a representative of PwC noted that much of the work of auditing Level 1 mutual fund assets is outsourced to lower-cost foreign locations.
} 
of different potential coefficients and/or mathematical transformations, we cannot specify ex ante what particular type of transformation may be expected. We thus propose our first research question as follows:

RQ1: In an audit fee model, does the log transformation provide the best fit for assets valued using different valuation input levels?

In many audit fees studies, size variables are included in the fee models as control variables, while non-size variables are the main focus of the research. Control variables are designed to allow for more rigorous testing of the variables of interest by accounting for the variance associated with the control variables. If alternative transformations of size variables result in a better model fit than the traditional log transformation, then the effects of size can be better controlled for, resulting in a more rigorous test of non-size variables. The enhanced model specification could result in different significance levels of the non-size variables. For the models we develop, we also seek to determine whether different transformations of size variable may influence the coefficients and significance levels of the non-size variables. This is the second research question of our study:

RQ2: Do the coefficients and significance levels of non-size variables differ between audit fee models in which the log transformation is used and models in which the transformation of the size variables is permitted to vary?

\section{RESEARCH METHOD}

\section{Sample}

We obtained data on all of the closed-end mutual funds in the Morningstar Direct database for the years 2010 and 2011. Morningstar contained 1,246 closed-end fund-years for this period. We then obtained the annual reports for these funds to hand-collect data on the total dollar amount of assets valued using Level 1, 2, and 3 valuation inputs. Based on availability of the annual reports and the various control variables, our sample was reduced to 948 closed-end fund-years and represents 489 unique closed-end funds, with 459 funds appearing in both years.

\section{Audit Fee Model}

We first run the audit fee model using the traditional log of total assets specification. We then use stepwise regression to analyze the best-fitting transformation of the fair valued assets in our audit fee model. We include variables with the following seven mathematical forms for Level 1, Level 2, and Level 3 assets: raw dollars, log, square root, cube root, fourth root, fifth root, and sixth root, resulting in 21 possible asset variables (seven mathematical transformations by three levels of asset valuation inputs) in the stepwise model. ${ }^{12}$ We specify that the stepwise process should stop adding variables when the p-value exceeds 0.05 . To assess whether different transformations of the audit fee (as the dependent variable) provide a better-fitting model, we also compare the model using the log of audit fee with the model allowing for different transformations of audit fees.

Drawing upon the limited literature on audit fees in the mutual fund business (e.g., Cullinan 2002; J. Booth, L. Booth, and Deli 2012), we include a number of control variables in the audit fee models. First, we control for the composition and performance of the funds. Similar to fair valued assets, non-fair valued assets, fair valued liabilities, and non-fair valued liabilities will need more auditor effort and are included as control variables. If a fund holds more securities, then more audit effort will be needed, so we include the total number of different securities held by the fund. Cash is expected to be easier to audit than security holdings; we therefore include the percentage of cash held by the fund. Foreign investments require an auditor to assess not only the fair value of the asset in a foreign currency, but also the translation of the foreign currency into U.S. dollars, which is expected to require more audit effort. We also control for the annual return of the fund. ${ }^{13}$

We also control for the administrative characteristics of the funds. Many funds are part of larger fund families that share the same administrative and control structure and processes. Because the costs incurred by the auditor in evaluating the internal control structure can be shared among the funds in the fund family, we include the fund family size in the audit fee model. Older funds are expected to have more experience with the security valuation and reporting processes, potentially resulting in lower audit fees, and funds with greater portfolio turnover are expected to have higher audit fees because there will be more realized gains and losses for an auditor to consider. To control for other unknown factors that may cause certain funds to incur

\footnotetext{
12 Note that this process could have resulted in multiple measures of Level $\mathrm{X}$ assets being included in the model.

${ }^{13}$ In untabulated analyses, we also included the Morningstar risk rating as a control variable. Inclusion of this variable did not materially alter our results, and the risk variable itself was not significant. Due to missing data for 113 fund-years, which would have resulted in the loss of a large number of observations, we present the more parsimonious audit fee model excluding the Morningstar risk measure.
} 


\section{TABLE 1 \\ Variable Definitions}

Variable

Audit fees

Level 1 assets

Level 2 assets

Level 3 assets

Total assets

Non-fair valued assets

Fair valued liabilities

Non-fair valued liabilities

Number of securities

Percentage of cash

Percentage of foreign securities

Fund return

Fund family size

Fund age

Portfolio turnover

Expense ratio

Auditor market share

Big 4

\section{Definition}

dollar amount of audit fees charged by an auditor.

fair value assets using Level 1 inputs (in thousands).

fair value assets using Level 2 inputs (in thousands).

fair value assets using Level 3 inputs (in thousands).

a fund's total assets (in thousands).

a fund's non-fair value assets (in thousands).

a fund's fair value liabilities (in thousands).

a fund's non-fair value liabilities (in thousands).

number of securities held by a fund.

the percentage of cash held in a fund as of the year-end.

the percentage of foreign securities in a fund as of the year-end.

a fund's yearly NAV return percentage.

the number of funds in a fund family.

the number of years since a fund's inception.

a fund's portfolio turnover percentage.

management fees, administrative fees, operating costs, and other costs (after excluding audit fees)

incurred by a fund divided by average net assets.

the percentage market share, based on audit fees, of a fund's auditor.

a dummy variable coded as 1 if a fund's auditor is a Big 4 firm, and 0 otherwise.

higher fees than other funds, we include the overall fund expense ratio (which includes management fees, administrative fees, operating costs, etc., all scaled by assets) from which we have removed the effect of audit fees.

Finally, we include variables to control for the characteristics of the auditors performing the audits. We control auditor market share (e.g., Craswell et al. 1995; Ferguson et al. 2003) in our audit fee model. We also include a Big 4 dummy variable to control for whether the fund has a Big 4 auditor.

All data are winsorized at 1 percent and 99 percent. We define and summarize all of the variables in Table 1.

\section{RESULTS}

\section{Descriptive Data}

Descriptive data for our sample are presented in Table 2. The mean audit fee is $\$ 45,509$, with a maximum audit fee of $\$ 181,000$. Level 2 assets is the largest asset category, with the mean fund having approximately \$299 million of Level 2 valued assets. Level 3 assets are the smallest category, with a mean of Level 3 valued assets of about $\$ 6.5$ million. Total fund assets average about $\$ 475$ million. The mean fund family contains 45.6 funds. The non-fair valued assets, fair valued liabilities, and non-fair valued liabilities average about \$13 million, \$2.5 million, and \$79 million, respectively. The mean fund holds 185.33 different securities in its portfolio. The percentage of assets held in cash and foreign securities average 2.88 percent and 11.37 percent, respectively. The mean fund has a return of 8.91 percent, is 13.82 years old, has a portfolio turnover of 47.77 percent, and has an expense ratio (with the effects of audit fees removed) of 1.53 percent of assets. The Big 4 accounting firms audit 96 percent of these closed-end funds.

\section{Regression Models}

Table 3 presents the results of the audit fee model using the traditional log-log model in which log transformations of assets, other size measures, and of audit fees are used. The model's adjusted $\mathrm{R}^{2}$ is 0.4368 . Table 4 presents the results of our stepwise regression model. There are two differences between the model specification in Table 3 and the model specification for the base model on Table 4. First, the log of assets variable was removed (because the size variables are added in subsequent steps). Second, the number of funds in the fund family was substituted for the log of funds in the fund family. ${ }^{14}$ The higher $\mathrm{R}^{2}$

\footnotetext{
${ }^{14}$ Consistent with the traditional $\log$ size/log audit fee relationship, we used the log of fund family size in the regression model presented in Table 3 . In Table 4, similar to our process with the asset size variables, we include as potential variables in preliminary stepwise analyses the number of funds in the fund family, and various transformations (e.g., log, square root). The raw number of funds in the fund family (with no mathematical transformation) was the only form of this variable that entered the model, and is the variable used as a control variable in Table 4.
} 
TABLE 2

Descriptive Statistics

Sample Size $=948$

\begin{tabular}{|c|c|c|c|c|c|c|c|}
\hline Variable & Mean & Std. Dev. & Q1 & Median & Q3 & Min. & Max. \\
\hline Audit fees & $\$ 45,509$ & $\$ 28,817$ & $\$ 28,200$ & $\$ 37,887$ & $\$ 56,200$ & $\$ 9,866$ & $\$ 181,000$ \\
\hline Level 1 assets $^{\mathrm{a}}$ & $\$ 145,162$ & $\$ 304,437$ & $\$ 0$ & $\$ 5,587$ & $\$ 124,403$ & $\$ 0$ & $\$ 1,560,827$ \\
\hline Level 2 assets $^{\mathrm{a}}$ & $\$ 299,240$ & $\$ 352,084$ & $\$ 43,077$ & $\$ 163,119$ & $\$ 445,216$ & $\$ 0$ & $\$ 1,655,622$ \\
\hline Level 3 assets $^{\mathrm{a}}$ & $\$ 6,460$ & $\$ 22,945$ & $\$ 0$ & $\$ 0$ & $\$ 415$ & $\$ 0$ & $\$ 156,448$ \\
\hline Total assets ${ }^{\mathrm{a}}$ & $\$ 474,985$ & $\$ 474,667$ & $\$ 141,216$ & $\$ 304,606$ & $\$ 648,525$ & $\$ 30,303$ & $\$ 2,470,536$ \\
\hline Fund family size & 45.60 & 47.13 & 5.00 & 25.00 & 90.00 & 1.00 & 122.00 \\
\hline Non-fair valued assets ${ }^{a}$ & $\$ 12,961$ & $\$ 21,100$ & $\$ 2,061$ & $\$ 5,706$ & $\$ 14,778$ & $\$ 82$ & $\$ 140,590$ \\
\hline Fair valued liabilities $^{\mathrm{a}}$ & $\$ 2,563$ & $\$ 8,953$ & $\$ 0$ & $\$ 0$ & $\$ 386$ & $\$ 0$ & $\$ 62,379$ \\
\hline Non-fair valued liabilities ${ }^{a}$ & $\$ 79,128$ & $\$ 132,950$ & $\$ 3,129$ & $\$ 22,571$ & $\$ 93,046$ & $\$ 57$ & $\$ 741,999$ \\
\hline Number of securities & 185.33 & 154.48 & 84.50 & 132.50 & 232.50 & 27.00 & 927.00 \\
\hline Percentage of cash & $2.88 \%$ & $6.20 \%$ & $0.00 \%$ & $0.33 \%$ & $3.00 \%$ & $0.00 \%$ & $38.34 \%$ \\
\hline Percentage of foreign securities & $11.37 \%$ & $24.72 \%$ & $0.00 \%$ & $0.00 \%$ & $8.94 \%$ & $0.00 \%$ & $98.77 \%$ \\
\hline Fund return & $8.91 \%$ & $10.77 \%$ & $1.88 \%$ & $8.83 \%$ & $16.61 \%$ & $-22.18 \%$ & $38.99 \%$ \\
\hline Auditor market share & $23.00 \%$ & $5.90 \%$ & $20.80 \%$ & $24.20 \%$ & $28.80 \%$ & $0.10 \%$ & $28.80 \%$ \\
\hline Big 4 & 0.96 & 0.20 & 1.00 & 1.00 & 1.00 & 0.00 & 1.00 \\
\hline Fund age & 13.82 & 8.97 & 7.00 & 12.00 & 19.00 & 1.00 & 53.00 \\
\hline Portfolio turnover & $47.77 \%$ & $60.78 \%$ & $12.00 \%$ & $26.00 \%$ & $62.00 \%$ & $1.00 \%$ & $367.00 \%$ \\
\hline Expense ratio & $1.53 \%$ & $0.60 \%$ & $1.14 \%$ & $1.43 \%$ & $1.82 \%$ & $0.44 \%$ & $3.95 \%$ \\
\hline
\end{tabular}

Winsorizing is at the 1 percent and 99 percent levels.

${ }^{\mathrm{a}}$ In thousands.

All variables are defined in Table 1.

for the Step 1 model in Table 1 (relative to the model in Table 3) supports the notion that allowing the mathematical form of the size/complexity variables to differ (in this case, the fund family size) can enhance the explanatory power of audit fee models.

The full model, in Step 3, has an adjusted $\mathrm{R}^{2}$ of 0.5207 , which is greater than the adjusted $\mathrm{R}^{2}(0.4368)$ in the log-log model presented in Table 3. An analysis of the significance of the change in $\mathrm{R}^{2}$ from the model in Table 3 to the model in Step 3 on Table 4 yields a Z-statistic of -6.1116 , indicating that the incremental $\mathrm{R}^{2}$ of the stepwise model relative to the log-log model in Table 3 is significant at $\mathrm{p}<0.001$. We also include on the stepwise tables the prediction sum of squares (PRESS), which differs from the sum of squares of the residual error (SSE) in that each fitted value for certain observations is obtained from the remaining $\mathrm{n}-1$ observations. The smaller the PRESS value, the better the model's predictive ability is expected to be. We also present $\mathrm{C}(\mathrm{p})$, which is designed to address the issue of overfitting when multiple measures are considered in stepwise regression (i.e., the residual sum of squares always gets smaller when more variables are added to a model). $\mathrm{C}(\mathrm{p})$ is related to adjusted $\mathrm{R}^{2}$, but includes a heavier penalty for increasing the number of independent variables. A lower $\mathrm{C}(\mathrm{p})$ reflects a better model fit.

In the stepwise regression process, only one measure for each of the different types of fair valued assets (i.e., assets valued using Level 1, 2, and 3 valuation inputs) enters into the model. As shown in Table 4, the Level 3 assets variable enters into the model with a cube root transformation in Step 1. ${ }^{15}$ The Level 1 assets variable enters into the model with a log transformation in Step 2, and the Level 2 assets variable enters into the model with a square root transformation in Step 3. Consistent with the traditional audit fee model, the log transformation of the Level 1 assets provides the best fit in the audit fee model. However, our results show that the square root transformation provides the best fit for Level 2 assets and a cube root transformation provides the best fit for Level 3 assets. None of the other transformations of the assets valued using the various levels of valuation inputs are significant at $\mathrm{p} \leq 0.05$. With regard to RQ1, our results indicate that the most appropriate mathematical transformations of size variables in audit fee models can differ depending on the complexity of the asset valuation process, and the $\log$ transformation therefore does not necessarily provide the best fit.

With regard to RQ2, the significance of some of the non-size variables is different between the log-log model in Table 3 and the final (Step 3) model in Table 4. For example, portfolio turnover is highly significant in Table 3, but only marginally

15 While Level 3 assets are the smallest category of assets, variation in this type of asset appears to have a strong relationship with variations in the audit fee. 
TABLE 3

Traditional Log-Log Audit Fee Model

Log of Audit fee $=f(\log$ of total assets + all control variables $)$

Variable
Intercept
Log of Total assets
Log of Fund family size
Log of Non-fair valued assets
Log of Fair valued liabilities
Log of Non-fair valued liabilities
Log of Number of securities
Percentage of cash
Fund return
Percentage of foreign securities
Auditor market share
Big 4
Log of Fund age
Portfolio turnover
Expense ratio
$\mathrm{n}$
Adjusted $\mathrm{R}^{2}$
Prediction sum of squares (PRESS)

\begin{tabular}{c} 
Log-Log Model \\
\hline 8.415 \\
0.182 \\
-0.137 \\
-0.008 \\
0.011 \\
0.000 \\
0.026 \\
-0.007 \\
0.000 \\
0.003 \\
-2.467 \\
0.490 \\
-0.029 \\
0.001 \\
0.178 \\
948 \\
0.4368 \\
175.0529
\end{tabular}

\begin{tabular}{ccc}
\multicolumn{1}{c}{ p-value } & VIF \\
\hline$<0.0001 * * *$ & & 0.00 \\
$<0.0001 * * *$ & & 2.97 \\
$<0.0001 * * * *$ & & 1.53 \\
0.617 & & 2.66 \\
$0.017 * *$ & 1.42 \\
0.980 & 2.67 \\
0.227 & 1.45 \\
$0.003 * * *$ & 1.11 \\
0.887 & 1.06 \\
$<0.0001 * * *$ & 1.15 \\
$<0.0001 * * *$ & 2.51 \\
$<0.0001 * * *$ & 2.59 \\
0.172 & 1.28 \\
$0.001 * * * *$ & 1.32 \\
$<0.0001 * * *$ & 1.58 \\
&
\end{tabular}

**, *** Indicate that the reported coefficient is significant at 0.05 and 0.01 , respectively.

Consistent with the literature, we took the log transformation for Fund family size, Non-fair valued assets, Fair valued liabilities, Non-fair valued liabilities, Number of securities, and Fund age.

All variables are defined in Table 1.

significant in the final column of Table 4. In addition, we tested the differences in the coefficients of the control variables between the traditional model in Table 3 and the last step of the stepwise regression model in Table 4. The results (untabulated) show that the coefficients of four variables-non-fair value assets, number of securities, audit market share, and expense ratio-are significantly different $(\mathrm{p} \leq 0.05)$ between the two models. A comparison of these differences indicates the transformation of asset measures can affect both the coefficients and the significance of these other variables. ${ }^{16}$ The divergent findings suggest that different mathematical transformation can influence not just the interpretation of the asset size variables, but can also affect the significance of other variables as well.

In Table 5, we compare the mathematical transformations and coefficients of the asset variables and the relevant range of data among the funds in our sample. The fourth row of Table 5 is the first order derivative that represents the slope of the relationship at each value (noted as X) for each category of assets. The fifth row shows the slope at the mean value for each category of assets. The results in Table 5 suggest that the relationship between Level 1 assets and audit fees is less steep than that of Level 2 assets, which is less steep than that of Level 3 assets. Using these results (and un-logging the audit fee), we calculate that a one million dollar increase in Level 1 assets, Level 2 assets, or Level 3 assets (from the mean level of such assets) would increase audit fees by $\$ 8.19, \$ 12.28$, and $\$ 395.32$, respectively. ${ }^{17}$

Based on the results in Table 4, we plot a graphical representation in Figure 1 to show the best-fitting functional forms over the range of the actual level of assets valued using the three levels of valuation inputs. Note that in Figure 1, both the coefficient

\footnotetext{
16 The only differences between the specifications of these two models are that the asset size variables are segregated into different levels and that the appropriate mathematical form of the size variables (including fund family size) are not presumed to be the log, but are permitted to vary to enhance the model fit.

17 The following is the calculation to compute the increased audit fee of $\$ 8.19$ for Level 1 assets. Start with the mean slope value: $0.00000018=(L N(\bar{y}+$ $\Delta y)-L N \bar{y}) / \Delta x$, where $\bar{y}$ denotes the mean of the audit fee and $\Delta y, \Delta x$ denote the changes of audit fee and Level 1 assets, respectively. For a $\$ 1$ million change of Level 1 assets, $L N(\bar{y}+\Delta y)-L N \bar{y}=L N[(\bar{y}+\Delta y) / \bar{y}]=0.00000018 * 1,000=0.00018$ (note that Level 1 assets are in thousands). Thus, $(\bar{y}$ $+\Delta y) / \bar{y}=e$ to the power of $0.00018=1.00017999753 .(\bar{y}+\Delta y) / \bar{y}=1+\Delta y / \bar{y}=1.00017999753 . \Delta y / \bar{y}=1.00017999753-1=0.00017999753$. Plug in $\bar{y}$ $=\$ 45,509$ (the mean audit fee), $\Delta y=0.00017999753 * \$ 45,509=\$ 8.191553$. The increased audit fees for increased Level 2 and Level 3 assets were obtained by the same calculation process.
} 


\section{TABLE 4}

Stepwise Regression Results (Dependent Variable: Log of Audit fees)

\section{Variable}

\section{Intercept}

Fund family size (not logged) $)^{\dagger}$

Log of Non-fair valued assets ${ }^{\dagger}$

Log of Fair valued liabilities ${ }^{\dagger}$

Log of Non-fair valued liabilities ${ }^{\dagger}$

Log of Number of securities ${ }^{\dagger}$

Percentage of $\operatorname{cash}^{\dagger}$

Fund return $^{\dagger}$

Percentage of foreign securities ${ }^{\dagger}$

Auditor market share ${ }^{\dagger}$

Big $4^{\dagger}$

Log of Fund age ${ }^{\dagger}$

Portfolio turnover ${ }^{\dagger}$

Expense ratio ${ }^{\dagger}$

Cube root of Level 3 assets

Log of Level 1 assets

Square root of Level 2 assets

$\mathrm{n}$

Adjusted $\mathrm{R}^{2}$

Prediction sum of squares (PRESS)

$\mathrm{C}(\mathrm{p})$

$$
\begin{gathered}
\text { Base Model } \\
\hline 9.959 * * * \\
-0.006 * * * \\
0.058^{* * *} \\
0.014 * * * \\
0.036 * * * \\
-0.011 \\
-0.007 * * * \\
-0.001 \\
0.003 * * * \\
-1.281 * * * \\
0.259 * * \\
-0.027 \\
0.001 * * \\
0.091 * * *
\end{gathered}
$$

\section{Base Model}

948
0.4506
170.2470
231.8756

\begin{tabular}{c} 
Step 1 \\
\hline $10.090^{* * *}$ \\
$-0.006^{* * *}$ \\
$0.058^{* * *}$ \\
$0.012^{* * *}$ \\
$0.032^{* * *}$ \\
$-0.047 * *$ \\
$-0.009^{* * *}$ \\
-0.001 \\
$0.003^{* * *}$ \\
$-1.301^{* * *}$ \\
$0.336 * * *$ \\
-0.026 \\
$0.001 * *$ \\
$0.061 * *$ \\
$0.010^{* * *}$ \\
\\
948 \\
0.4830 \\
160.3154 \\
164.6934
\end{tabular}

\begin{tabular}{c} 
Step 2 \\
\hline $9.832 * * *$ \\
$-0.005^{* * *}$ \\
$0.067 * * *$ \\
0.006 \\
$0.025 * * *$ \\
-0.031 \\
$-0.009 * * *$ \\
-0.001 \\
$0.002 * * *$ \\
$-1.001 * * *$ \\
$0.281^{* * *}$ \\
-0.022 \\
0.000 \\
$0.059 * *$ \\
$0.009 * * *$ \\
$0.022 * * *$ \\
948 \\
0.5104 \\
152.2288 \\
108.2402
\end{tabular}

Step 3

$10.114 * * *$

$-0.005 * * *$

$0.040 * * *$

0.004

0.014

$-0.062 * * *$

$-0.009 * * *$

$-0.001$

$0.002 * * *$

$-0.935 * * *$

$0.252 * *$

$-0.021$

$0.000^{*}$

$0.084 * * *$

$0.009 * * *$

$0.026 * * *$

$0.0003 * * *$

948

0.5207

149.3225

87.6036

$*, * *, * * *$ Indicate that the reported coefficient is significant at $0.10,0.05$, and 0.01 , respectively.

$\dagger$ Denotes the variables that were forced to enter the regression.

For Level 1 assets, Level 2 assets, and Level 3 assets, each of the following forms were available for the stepwise regression: original raw dollars, log, square root, cube root, fourth root, fifth root, and sixth root. The significance level for each step was set at the 5 percent level.

The comparison between the base log-log model in Table 3 and the model from Step 4:

Adj. $\mathrm{R}^{2}: 0.4368$ versus 0.5207 , with Z-statistics of -6.1116 ( $\mathrm{p}$-value $<0.001$ ).

and functional form vary. Consistent with the results shown in Table 5, Figure 1 shows that the relationship between Level 3 assets and audit fees is steeper than that of Level 2 assets, while the relationship between Level 2 assets and audit fees is steeper than that of Level 1 assets.

With regard to the mathematical form of the dependent variable (audit fees), we run our stepwise regression using the log transformation and other mathematical transformations of audit fee (raw fee, square root, etc.) and each of the mathematical

\section{TABLE 5}

\section{Comparison of Scale of Relationship between Level 1, 2, 3 Assets and Audit Fees}

\section{FV Assets Category}

Mathematical form in stepwise audit fee model

Functional form

Parameter estimate

First order derivative (a measure of slope; the greater, the steeper)

Slope values of mean

Slope values of Q1

Slope values of median

Slope values of Q3
Level 1

\begin{tabular}{lll}
\hline $\log$ & & Square Root \\
$\operatorname{Ln}(\mathrm{X})$ & $\mathrm{X}^{* *}(1 / 2)$ \\
0.026 & 0.0003 \\
$0.026 * \mathrm{X}^{* *}(-1)$ & $0.0003^{*}(1 / 2) * \mathrm{X}^{* *}(-1 / 2)$ \\
0.00000018 & 0.00000027 \\
$\mathrm{NA}$ & 0.00000072 \\
0.00000465 & 0.00000037 \\
0.00000021 & 0.00000022
\end{tabular}

Level 3

Cube Root

$\mathrm{X}^{* *}(1 / 3)$

0.009

$0.009 *(1 / 3) * X^{* *}(-2 / 3)$

0.00000865

NA

NA

0.00005392

Slope values of mean, Q1, median, and Q3 are derived by plugging mean, Q1, median, and Q3 (from Table 2) into the first order derivatives. The slope values represent the incremental (logged) audit fee associated with every $\$ 1,000$ dollar increase in the dollar amount of Level 1, 2, and 3 assets. Certain slopes are NA because the relevant descriptive statistic is 0 . 
FIGURE 1

Graphical Representation of the Log of Audit Fees Predicted from the Optimal Functional Forms (from Table 4) over the Range of Actual Data of the Three Fair Valued Asset Categories

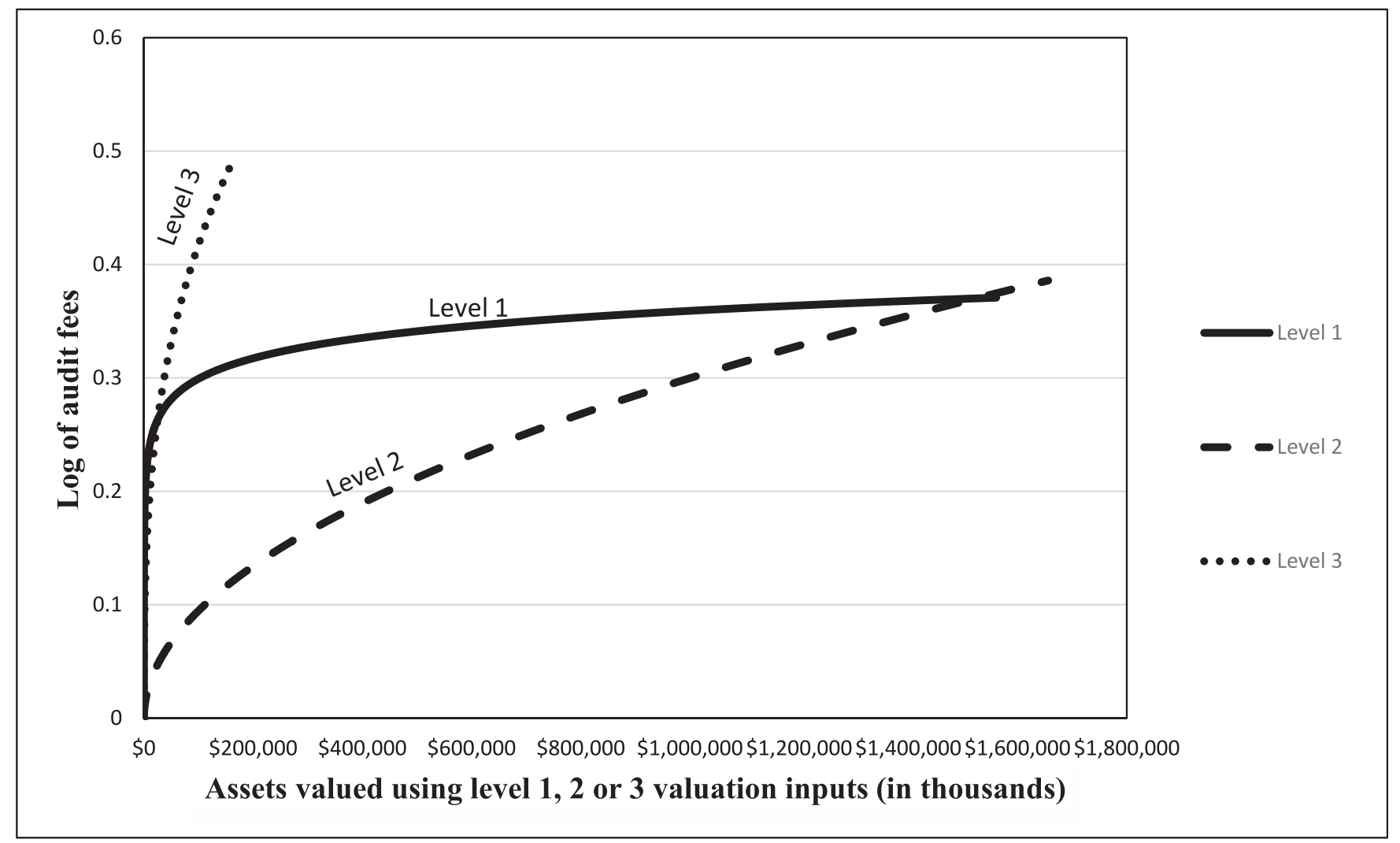

transformations of fair valued assets. A summary of our results is presented in Table 6. The log transformation yields the highest adjusted $\mathrm{R}^{2}$ of 0.521 after Step 3 and the $C(\mathrm{p})$ value is 87.60 (the lowest). Consistent with other auditing literature, the $\log$ transformation of audit fee still appears to provide the best model fit.

\section{Generalizability Analysis}

To examine whether our findings in the mutual fund industry are generalizable, we examine an audit fee model (based on Huang, Parker, Yan, and Lin 2014) for a broad-based sample of publicly traded firms. We obtained data on fair valued assets and other common audit fee model variables for all public companies in the Compustat database for the years 2011 and 2012. We then restricted this broad-based sample to the companies for which the percentage of fair value assets is above 1 percent to meaningfully assess the influence of fair valued assets on audit fees. Compustat contained 4,234 firm-years with fair valued assets over 1 percent for this period. Based on availability of the audit fee data and the various control variables, our broadbased sample was reduced to 4,130 firm-years. There are 2,071 and 2,059 observations from year 2011 and year 2012 , respectively, with 1,726 companies having repeated observations.

As shown in Table 7, the model using the log of total assets has an adjusted $\mathrm{R}^{2}$ of 0.7935 . We then use the stepwise regression approach in which we segregate the assets into the three valuation levels and allow the mathematical forms of the assets to vary. The adjusted $\mathrm{R}^{2}(0.8007)$ of the stepwise model is higher than that of the base model (0.7935). There is also variation in the most appropriate transformation of the asset levels. While the log transformation of the Level 1 assets provides the best fit in the audit fee model, the Level 2 and Level 3 assets have different transformations in the best fit model. Furthermore, our results show that the significant levels of some control variables are different between the base model and stepwise regression model. For example, the auditor change variable is not significant in the base model, but is significant (pvalue $<0.05)$ in the stepwise regression model. 
TABLE 6

\section{Stepwise Regression Results with Different Transformations of "Audit Fees"}

\begin{tabular}{|c|c|c|c|c|c|c|c|}
\hline Variable & Raw Dollars & Log & Square Root & $\begin{array}{l}\text { Cube } \\
\text { Root }\end{array}$ & $\begin{array}{c}\text { Fourth } \\
\text { Root }\end{array}$ & Fifth Root & $\begin{array}{l}\text { Sixth } \\
\text { Root }\end{array}$ \\
\hline $\begin{array}{l}\text { Cube root of } \\
\text { Level } 3 \text { assets }\end{array}$ & Step 1 & Step 1 & Step 1 & Step 1 & Step 1 & Step 1 & Step 1 \\
\hline $\begin{array}{l}\text { Log of Level } 1 \\
\text { assets }\end{array}$ & Step 2 & Step 2 & Step 2 & Step 2 & Step 2 & Step 2 & Step 2 \\
\hline $\begin{array}{l}\text { Square root of } \\
\text { Level } 2 \text { assets }\end{array}$ & & Step 3 & Step 3 & Step 3 & Step 3 & Step 3 & Step 3 \\
\hline $\begin{array}{l}\text { Raw Dollars of } \\
\text { Level } 2 \text { assets }\end{array}$ & Step 3 & & & & & & \\
\hline $\mathrm{n}$ & 948 & 948 & 948 & 948 & 948 & 948 & 948 \\
\hline Adj. $R^{2}$ after Step 3 & 0.4515 & 0.5207 & 0.4715 & 0.4901 & 0.4988 & 0.5037 & 0.5069 \\
\hline $\mathrm{C}(\mathrm{p})$ & 87.8276 & 87.6036 & 88.9902 & 88.7672 & 88.5710 & 88.4244 & 88.3141 \\
\hline
\end{tabular}

Step $\mathrm{X}$ represents the order in which the variables entered the stepwise regression models.

Thirteen variables (the same as Table 4) are forced to enter the regression. For Level 1 assets, Level 2 assets, and Level 3 assets, each of the following forms were available for the stepwise regression: original raw dollars, log, square root, cube root, fourth root, fifth root, and sixth root. The significance level for each step was set at the 5 percent level.

\section{TABLE 7}

\section{Generalizability Analysis}

\begin{tabular}{|c|c|c|}
\hline \multicolumn{3}{|c|}{ Generalizability Analysis } \\
\hline Variable & $\begin{array}{c}\text { Base } \\
\text { Model }\end{array}$ & $\begin{array}{c}\text { Stepwise } \\
\text { Regression } \\
\text { Model }\end{array}$ \\
\hline Intercept & $10.236 * * *$ & $11.072 * * *$ \\
\hline Log of Total assets & $0.521 * * *$ & \\
\hline Log of Non-fair valued assets ${ }^{\dagger}$ & & $0.365 * * *$ \\
\hline Percentage of receivables and inventory ${ }^{\dagger}$ & $-0.559 * * *$ & $-0.709 * * *$ \\
\hline Foreign operations $s^{\dagger}$ & -0.050 & -0.040 \\
\hline Debt ratio ${ }^{\dagger}$ & $-0.073 *$ & -0.015 \\
\hline Return on assets ${ }^{\dagger}$ & $-0.073^{* *}$ & -0.009 \\
\hline $\operatorname{Loss}^{\dagger}$ & $0.189 * * *$ & $0.148 * * *$ \\
\hline Restatement $^{\dagger}$ & 0.034 & 0.023 \\
\hline Ratio of non-audit fees to audit fees ${ }^{\dagger}$ & $-0.254 * * *$ & $-0.281 * * *$ \\
\hline Auditor change ${ }^{\dagger}$ & 0.048 & $0.070 * *$ \\
\hline $\operatorname{Big} 4^{\dagger}$ & $0.611 * * *$ & $0.625 * * *$ \\
\hline Industry fixed effects & Controlled & Controlled \\
\hline Cube root of Level 3 assets & & $0.037 * * *$ \\
\hline Log of Level 1 assets & & $0.062 * * *$ \\
\hline Log of Level 3 assets & & $0.048 * * *$ \\
\hline Sixth root of Level 2 assets & & $0.025 * * *$ \\
\hline $\mathrm{n}$ & 4,130 & 4,130 \\
\hline Adjusted $\mathrm{R}^{2}$ & 0.7935 & 0.8007 \\
\hline
\end{tabular}

$*, * *, * * *$ Indicate that the reported coefficient is significant at $0.10,0.05$, and 0.01 , respectively.

$\dagger$ Denotes the variables that were forced to enter the stepwise regressions.

These four variables are listed in the order they entered the stepwise regressions.

For Level 1 assets, Level 2 assets, and Level 3 assets, each of the following forms were available for the stepwise regression: original raw dollars, log, square root, cube root, fourth root, fifth root, and sixth root. The significance level for each step was set at the 5 percent level. 
Our generalizability analysis indicates that allowing for different mathematical transformations of assets can provide a more rigorous test of the significance of non-size variables. The results also suggest that the most appropriate transformations of fair value assets can differ depending on the type of valuation inputs used to determine the fair value of the assets.

\section{CONCLUSIONS AND IMPLICATIONS}

We assess the applicability of the widely used log transformation of assets in audit fee models, and we consider whether the appropriate transformation may differ depending on different levels of fair value inputs used in financial reporting. In the closed-end mutual fund setting, we find that the influence on audit fees of assets with different valuation complexity is reflected in different mathematical transformations. The relationships between more complex assets (such as Level 3 assets) and audit fees are much steeper and have different mathematical transformations than less complex assets (such as Level 1 assets). These results indicate that the complexity associated with auditing more subjectively valued assets may affect audit fees in a manner that is not fully captured by the traditional log transformation. Future research may consider using the stepwise approach to more accurately model the relationship between complexly valued assets and audit fees.

We also find that the significance of other variables in audit fee models can vary based on the transformation used for the asset size measure. Many studies use a logged measure of assets for control purposes, and are interested in adding some variable (e.g., auditor specialization) to an existing audit fee model. We find that the significance of other variables can change when a more suitable mathematical transformation of various types of assets is used. We therefore suggest that future audit fee studies assess alternative mathematical transformations of client size variables, particularly when the asset composition is complex. More robust tests can then be made of other variables in audit fee models that may be of primary interest in other research.

\section{REFERENCES}

American Institute of Certified Public Accountants (AICPA). 2002. Consideration of Fraud in a Financial Statement Audit. Statement on Auditing Standards No. 99. New York, NY: AICPA.

American Institute of Certified Public Accountants (AICPA). 2012. AICPA Audit and Accounting Guides: Investment Companies. New York, NY: AICPA.

Barlev, B., and J. R. Haddad. 2004. Dual accounting and the Enron control crisis. Journal of Accounting, Auditing \& Finance 19 (3): 343-359.

Benoit, K. 2011. Linear Regression Models with Logarithmic Transformations. Available at: http://www.kenbenoit.net/courses/ME104/ logmodels2.pdf

Benston, G. J. 2008. The shortcomings of fair-value accounting described in SFAS 157. Journal of Accounting and Public Policy 27 (2): 101-114.

Booth, J. R., L. C. Booth, and D. Deli. 2012. Managerial incentives and audit fees: Evidence from the mutual fund industry. Accounting and Finance Research 1 (May): 76-94.

Carroll, T. J., T. J. Linsmeier, and K. R. Petroni. 2003. The reliability of fair value versus historical cost information: Evidence from closed-end mutual funds. Journal of Accounting, Auditing \& Finance (Winter): 1-23.

Cherkes, M., J. Sagi, and R. Stanton. 2009. A liquidity-based theory of closed-end funds. Review of Financial Studies 22: $257-297$.

Chung, D. Y., and W. D. Lindsay. 1988. the pricing of audit services: The Canadian perspective. Contemporary Accounting Research 5 (1): $19-46$.

Craswell, A., J. Francis, and S. Taylor. 1995. Auditor brand names and industry specializations. Journal of Accounting \& Economics 20 (3): 297-322.

Cullinan, C. P. 2002. SEC audit requirements and audit fees. Research in Accounting Regulation 15: 135-150.

De Jonghe, F., and M. Vrolix. 2005. Auditing mutual fund: Looking beyond the accounts. Financieel Forum/Bank-en Financiewezen: 416-422.

Ettredge, M. L., Y. Xu, and H. S. Yi. 2014. Fair value measurements and audit fees: Evidence from the banking industry. Auditing: A Journal of Practice \& Theory 33 (3): 33-58.

Fan, J. P. H., and T. J. Wong. 2005. Do external auditors perform a corporate governance role in emerging markets? Evidence from East Asia. Journal of Accounting Research 43 (1): 35-72.

Ferguson, A., J. Francis, and D. Stokes. 2003. The effects of firm-wide and office-level industry expertise on audit pricing. The Accounting Review 78 (2): 113-136.

Fields, L. P., D. R. Fraser, and M. S. Wilkins. 2004. An investigation of the pricing of audit services for financial institutions. Journal of Accounting and Public Policy 23 (1): 53-77.

Financial Accounting Standards Board (FASB). 2006. Fair Value Measurements. Statement of Financial Accounting Standards No. 157. Norwalk, CT: FASB. 
Financial Accounting Standards Board (FASB). 2011. Fair Value Measurement (Topic 820). Release No. 2011-04. Available at: http://www. fasb.org/cs/BlobServer?blobcol=urldata\&blobtable=MungoBlobs\&blobkey=id\&blobwhere=1175822486936\&blobheader=application/ pdf

Firth, M. 1985. An analysis of audit fees and their determinants in New Zealand. Auditing: A Journal of Practice \& Theory 4 (2): $23-37$.

Francis, J. R. 1984. The effect of audit firm size on audit prices: A study of the Australian market. Journal of Accounting and Economics 6 (2): 133-151.

Francis, J., K. Reichelt, and D. Wang. 2005. The pricing of national and city-specific reputations for industry expertise in the U.S. audit market. The Accounting Review 80 (1): 113-136.

Goldstein, A. M. 2009. Pricing and valuation of mutual fund shares. In ABCS of Mutual Funds. New York, NY: Practicing Law Institute.

Goncharov, I., E. Riedl, and T. Sellhorn. 2014. Fair value and audit fees. Review of Accounting Studies 19 (1): $210-241$.

Hay, D., W. R. Knechel, and N. Wong. 2006. Audit fees: A meta-analysis of the effect of supply and demand attributes. Contemporary Accounting Research 23 (1): 141-191.

Huang, H., R. Parker, Y. Yan, and Y. Lin. 2014. CEO turnover and audit pricing. Accounting Horizons 28 (2): $297-312$.

International Accounting Standards Board (IASB). 2011. Fair Value Measurements. IFRS 13. London, U.K.: IASB.

Landsman, W. R. 2007. Is fair value accounting information relevant and reliable? Evidence from capital market research. Accounting and Business Research (Special Issue/ International Accounting Policy Forum):19-30.

Louwers, T., R. J. Ramsay, D. H. Sinason, J. R. Strawser, and J. C. Thibodeau. 2013. Auditing and Assurance Services. 5th edition. New York, NY: McGraw-Hill.

Martin, R. D., J. S. Rich, and T. J. Wilks. 2006. Auditing fair value measurements: A synthesis of relevant research. Accounting Horizons 20 (3): 287-303.

Penman, S. H. 2007. Financial reporting quality: Is fair value a plus or a minus? Accounting and Business Research (Special Issue/ International Accounting Policy Forum): 33-44.

Picconi, M., and J. K. Reynolds. 2013. Audit Fee Theory and Estimation: A Consideration of the Logarithmic Audit Fee Model. Working paper, The College of William \& Mary and Florida State University.

Ryan, S. G. 2008. Accounting in and for the subprime crisis. The Accounting Review 83 (6): 1605-1638.

Securities and Exchange Commission (SEC). 2011. In the Matter of Morgan Asset Management, Inc.; Morgan Keegan \& Company, Inc., James C. Kelsoe, Jr.; and Joseph Thompson Weller, CPA, Respondents. Administrative Proceeding File No. 3-13847. Available at: http://www.sec.gov/litigation/admin/2011/34-64720.pdf

Securities and Exchange Commission (SEC). 2012a. In the Matter of UBS Global Asset Management (Americas) Inc. Respondent. Administrative Proceeding File No. 3-14699. Available at: http://www.sec.gov/litigation/admin/2012/ia-3356.pdf

Securities and Exchange Commission (SEC). 2012b. In the Matter of KCAP Financial, Inc., Dayl W. Pearson, M. I. Wirth, CPA and R. J. Corless, Respondents. Administrative Proceeding File No. 3-15109. Available at: http://www.sec.gov/litigation/admin/2012/3468307.pdf

Securities and Exchange Commission (SEC). 2013. Valuation of Portfolio Securities and other Assets Held by Registered Investment Companies-Select Bibliography of the Division of Investment Management. Available at: http://www.sec.gov/divisions/ investment/icvaluation.htm

Simon, D. A. 1985. The audit service market: Additional empirical evidence. Auditing: A Journal of Practice \& Theory 5 (1): $71-78$.

Simunic, D. A. 1980. The pricing of audit services: Theory and evidence. Journal of Accounting Research 18: 161-190.

Song, C. J., W. B. Thomas, and H. Yi. 2010. Value relevance of FAS No. 157 fair value hierarchy information and the impact of corporate governance mechanisms. The Accounting Review 85 (4): 1375-1410.

Sydsaeter, K., and P. J. Hammond. 1995. Mathematics for Economic Analysis. Englewood Cliffs, NJ: Prentice Hall.

Wallace, W. A. 1980. The Economic Role of the Audit in Free and Regulated Markets. Rochester, NY: University of Rochester, Graduate School of Management. 
Copyright of Auditing: A Journal of Practice \& Theory is the property of American Accounting Association and its content may not be copied or emailed to multiple sites or posted to a listserv without the copyright holder's express written permission. However, users may print, download, or email articles for individual use. 